\title{
Cu Modified Pt Nanoflowers with Preferential (100) Surfaces for Selective Electroreduction of Nitrate
}

\author{
Ting Chen ${ }^{1, *} \mathbb{0}$, Yuxuan $\mathrm{Li}^{1}$, Luyan $\mathrm{Li}^{1}$, Yanjie Zhao ${ }^{1}$, Shuhua Shi ${ }^{1}$, Rongyan Jiang ${ }^{2}$ and \\ Houyi Ma ${ }^{3, *}$ \\ 1 School of Science, Shandong Jianzhu University, Jinan 250101, China; sdjzlyx@gmail.com (Y.L.); \\ liluyan@sdjzu.edu.cn (L.L.); zhaoyanjie@sdjzu.edu.cn (Y.Z.); sdsfhf@sdjzu.edu.cn (S.S.) \\ 2 School of Materials Science and Engineering, Shandong Jianzhu University, Jinan 250101, China; \\ ryjiang@sdjzu.edu.cn \\ 3 School of Chemistry and Chemical Engineering, Shandong University, Jinan 250100, China \\ * Correspondence: chenting@sdjzu.edu.cn (T.C.); hyma@sdu.edu.cn (H.M.)
}

Received: 10 May 2019; Accepted: 13 June 2019; Published: 15 June 2019

\begin{abstract}
Improving surface selectivity and maximizing electrode surface area are critical needs for the electroreduction of nitrate. Herein, preferential (100) oriented Pt nanoflowers with an extended surface area were prepared by potentiostatic deposition on carbon cloth (Pt NFs/CC), and then $\mathrm{Cu}$ atoms were adsorbed on the $\mathrm{Pt} \mathrm{NFs}(\mathrm{Cu} / \mathrm{Pt} \mathrm{NFs} / \mathrm{CC})$ for application of nitrate electroreduction. The results reveal that $\mathrm{Cu} / \mathrm{Pt} \mathrm{NFs} / \mathrm{CC}$ with $8.7 \% \mathrm{Cu}$ coverage exhibits a high selectivity for nitrate electroreduction to $\mathrm{N}_{2}$ following two steps: Nitrate firstly converts into nitrite on $\mathrm{Cu}$ sites adsorbed on $\mathrm{Pt}$ NFs, then nitrite subsequently selective reduction and ammonia oxidation to $\mathrm{N}_{2}$ occur on the large exposed (100) terraces in Pt NFs. In addition, electrocatalytic activity and selectivity of nitrate reduction strongly rely on the $\mathrm{Cu}$ surface coverage on $\mathrm{Pt} \mathrm{NFs}$, the lower activity of nitrate reduction is displayed with increase of $\mathrm{Cu}$ coverage. Accordingly, the selective reduction of nitrate to $\mathrm{N}_{2}$ is feasible at such nanostructured Pt nanoflowers modified with $\mathrm{Cu}$.
\end{abstract}

Keywords: Pt nanoflowers; preferential (100) orientation; Cu modification; electrocatalysts; nitrate electroreduction

\section{Introduction}

Nitrate, as an environmental pollutant, can cause the eutrophication of water bodies and some detrimental effects on water quality. Especially in drinking water, excessive nitrate can transform into the toxic nitrite which can sicken the human through methemoglobinemia and cancer $[1,2]$. Nitrate reduction is a significant process in the part of the nitrogen cycle because of its applications in nitrate removal, and the desired and targeted end-product is harmless nitrogen gas $\left(\mathrm{N}_{2}\right)$. Since nitrate can be reduced to $\mathrm{N}_{2}$ via denitrifying bacteria, the rate of this process is sluggish [3]. Therefore, developing other techniques for removing nitrate and achieving the selective conversion of nitrate to $\mathrm{N}_{2}$ is necessary. Electrochemical denitrification is not only an environmentally friendly approach but also an effective and promising method due to its relatively low investment costs and high product selectivity of nitrate reduction by using diverse electrocatalysts.

According to the mechanisms and main pathways during electroreduction of nitrate, the ratedetermining step is the conversion to nitrite, and the following nitrite reduction is a selective step where the kinetics and products are strongly dependent on the electrode materials, $\mathrm{pH}$, and electrode geometry [4]. It's worth noting that three routes have been presented for selective reduction of nitrite to $\mathrm{N}_{2}$ via the intermediates $\mathrm{N}_{(\mathrm{ads})}, \mathrm{N}_{2} \mathrm{O}_{(\mathrm{ads})}$, and $\mathrm{NH}_{\mathrm{x}}-\mathrm{NO}_{(\mathrm{ads})}$ respectively [5-8]. However, the mechanism of combination of two adsorbed nitrogen atoms to generate $\mathrm{N}_{2}$ is not well-founded, 
and the formation of $\mathrm{N}_{2}$ through the reduction of $\mathrm{N}_{2} \mathrm{O}_{(\text {ads }}$ is also challenging because of the high solubility of $\mathrm{N}_{2} \mathrm{O}$ [9]. Therefore, the $\mathrm{NH}_{\mathrm{x}(\mathrm{ads})}+\mathrm{NO}_{(\mathrm{ads})}$ route which has the potential to generate $100 \%$ $\mathrm{N}_{2}$ is especially remarkable and important although the highly selective activity is only achieved on the quasi-perfect $\mathrm{Pt}(100)$ surface in alkaline media. Unfortunately, $\mathrm{Pt}(100)$ surface is inactive for the rate-determining step at alkaline $\mathrm{pH}$ values [10]. Therefore, the design of a bimetallic electrocatalyst based on $\mathrm{Pt}(100)$ by introducing a "promoter" which can accelerate the nitrate reduction is an effective strategy for the selective reduction of nitrate to $\mathrm{N}_{2}$.

Bimetallic electrocatalysts based on $\mathrm{Pt}(100)$ have long been investigated for nitrate reduction in acid and neutral solutions, showing $\mathrm{NH}_{3}$ and $\mathrm{N}_{2} \mathrm{O}$ as the major final products [11-16]. However, for selecting $\mathrm{N}_{2}$ as the main product, the study of alkaline solutions is essential for nitrate reduction on such a catalyst which would make use of $\mathrm{Pt}(100)$. In alkaline media, $\mathrm{Pd} / \mathrm{Pt}(100)$ [17] electrode showed higher electrocatalytic activity for nitrate reduction, but leading no $\mathrm{N}_{2}$ as the product. In addition, compared with the $\mathrm{Cu} / \mathrm{Pt}(100)$ and $\mathrm{Rh} / \mathrm{Pt}(100)$ electrodes [18], the process of selectively reducing nitrate to $\mathrm{N}_{2}$ was proved effective by decorating a fractional $\mathrm{Cu}$ monolayer on $\mathrm{Pt}(100)$ signal crystal electrode. Indeed, $\mathrm{Cu}$ and $\mathrm{Rh}$ were identified as the most active catalysts under alkaline media $[19,20]$, which act as "promoters" for conversion nitrate to nitrite. However, the preferential adsorption of intermediate nitrite between the surface of promoter metal and $\mathrm{Pt}(100)$ would be the critical factor for reducing nitrate towards $\mathrm{N}_{2}$. Accordingly, the bimetallic system based on $\mathrm{Pt}(100)$ would require (i) the $\mathrm{Pt}(100)$ with extended surface areas that could both anchor the promoter metal atoms and expose enough (100) surface sites for adsorbing the nitrite and (ii) the appropriate coverage of the promoter metal that could achieve selective reduction to $\mathrm{N}_{2}$. Considering above, Pt nanostructured materials with a preferential (100) orientation [21-24] are more favorable for nitrate reduction and highly specific for the $\mathrm{N}_{2}$ selective formation by decorating a promoter metal, such as the low-cost copper.

In this paper, Cu modified Pt nanflowers with preferential (100) surfaces grew on carbon cloth substrate $(\mathrm{Cu} / \mathrm{Pt} \mathrm{NFs} / \mathrm{CC})$ by the two-step electrochemical deposition process, which can be directly used as the electrode for electroreduction of nitrate in alkaline media. The bimetallic system which combines Pt NFs and less $\mathrm{Cu}$ atoms $(\sim 8.7 \% \mathrm{Cu})$ could follow the two-step mechanism (nitrate reduction to nitrite on $\mathrm{Cu}$ and nitrite conversion to $\mathrm{N}_{2}$ on (100) sites in Pt NFs) to convert the harmful nitrate to harmless $\mathrm{N}_{2}$. On the contrary, the selective step for the generation of $\mathrm{N}_{2}$ would be hindered by increasing the coverage of $\mathrm{Cu}$, leading to a lower activity for nitrate reduction.

\section{Results and Discussion}

\subsection{Characterizations of Pt NFs/CC and Cu/Pt NFs/CC}

Pt NFs with preferential (100) surfaces were electrodeposited on carbon cloth $\left(1 \times 1 \mathrm{~cm}^{2}\right)$ via the potentiostatic deposition in $0.5 \mathrm{M} \mathrm{H}_{2} \mathrm{SO}_{4}$ containing $2 \mathrm{mM} \mathrm{H}_{2} \mathrm{PtCl}_{6}$ at the potential of $-0.1 \mathrm{~V}$ without any capping polymer. In this process, hydrogen, which is generated on the carbon cloth at $-0.1 \mathrm{~V}$, could reduce $\mathrm{Pt}$ cations and result in the formation of Pt nanoflowers with highly (100) oriented surfaces [25]. Figure 1A-D show the different magnification SEM images of Pt deposits on the carbon cloth. Figure 1A shows a large-scale SEM image of the carbon cloth after Pt electrodeposition, while the enlarged SEM image (Figure 1B) reveals that the carbon fibers are fully covered with the Pt deposited layer. Figure 1C further indicates that the unique surface state arises from assembling of Pt nanospheres wrapped around each carbon fiber, and the corresponding energy dispersive X-ray spectrometer (EDS) mapping image (inset of Figure 1C) shows the uniform distribution of Pt on each carbon fiber. As shown in a high-magnification SEM image (Figure 1D), the Pt nanosphere has a flower-like structure which is composed of numerous nanosheets, and the size of an individual Pt NF is approximately $700 \mathrm{~nm}$. The TEM image shown in Figure 1E further verifies that the Pt NFs are assembled with plenty of extremely thin nanosheets with the well-defined edges but the thickness can't be estimated from the TEM image. Figure 1F,G show the high-resolution transmission electron microscope (HRTEM) images of the Pt NFs chosen at random, the observed lattice fringes correspond 
to the (111) and (200) planes of Pt based on the interplanar distance measurement $(0.226 \mathrm{~nm}$ and $0.195 \mathrm{~nm}$ ). Although the presence (111) faces in HRTEM observation, the typical cyclic voltammogram, as shown in Figure 1H, confirms that the exposed active surface of the Pt NFs is predominantly $\mathrm{Pt}(100)$ which can be ascribed to the (100) step sites at the peak of $0.28 \mathrm{~V}$ and (100) terraces with a wide shoulder located at $0.35 \mathrm{~V}$ [26]. According to the aforementioned characterizations and compared with other three-dimensional platinum nanostructures reported recently [13,23], the as-prepared $\mathrm{Pt} \mathrm{NFs/CC} \mathrm{is}$ more suitable for investigating the nitrate reduction since (i) the flower-like structure with numerous nanosheets would give rise to the surface areas and facilitate estimating the current density of the products obtained from nitrate reduction; (ii) the boarder exposed $\mathrm{Pt}(100)$ steps and terraces should provide enough sites for decorating a "promoter" metal for the conversion of nitrate to nitrite and subsequently contribute to selective reducing nitrite to $\mathrm{N}_{2}$ in alkaline solutions.
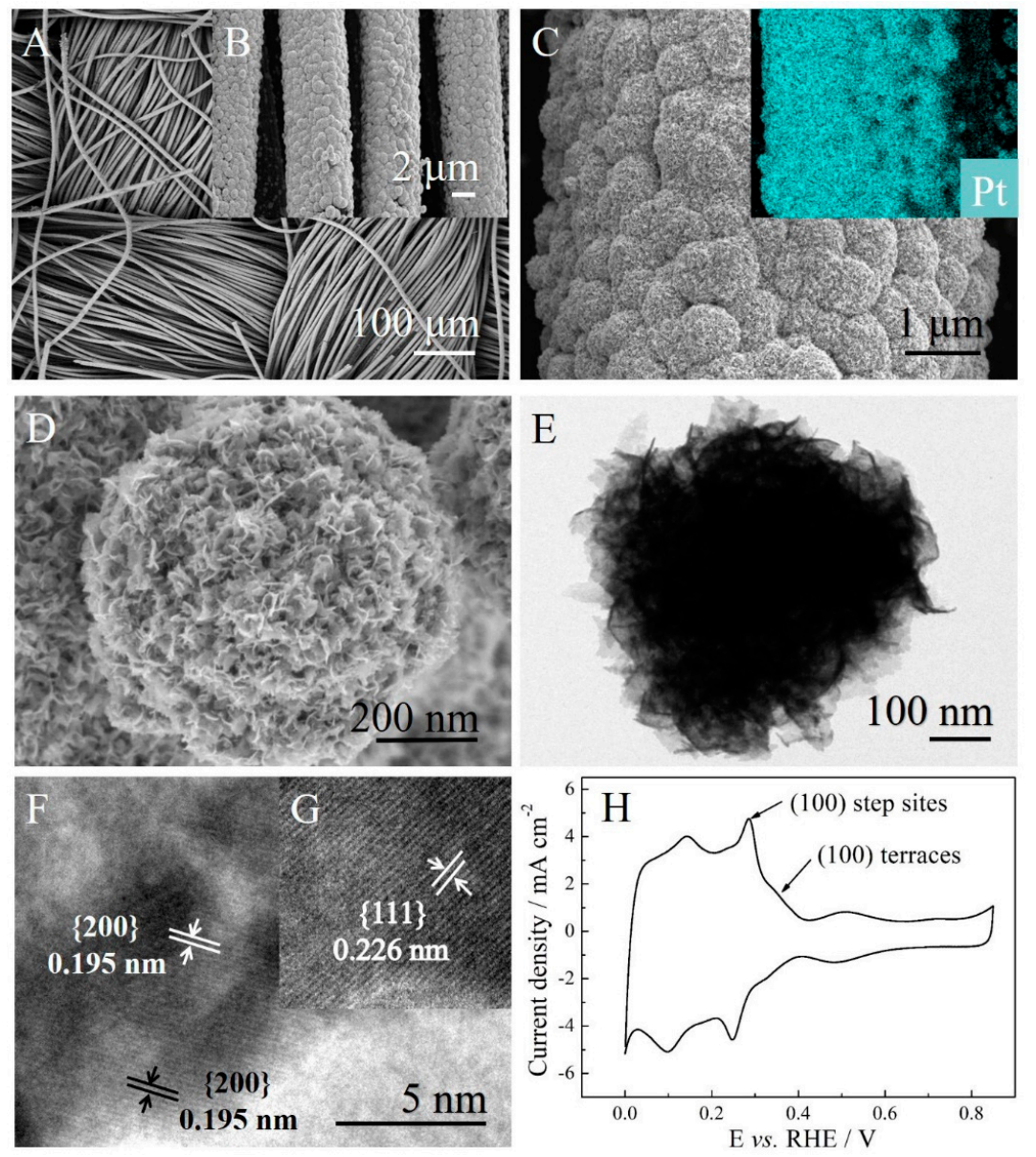

Figure 1. SEM images of Pt NFs/CC (A-D) at different magnifications. Inset of $(\mathbf{C})$ is the corresponding elemental mapping image; TEM image (E), HRTEM images (F,G) of the Pt NF; cyclic voltammogram (H) for the Pt NFs/CC in $0.5 \mathrm{M} \mathrm{H}_{2} \mathrm{SO}_{4}$ at $20 \mathrm{mV} \mathrm{s}^{-1}$.

$\mathrm{Cu} / \mathrm{PtNFs} / \mathrm{CC}$ was prepared by carrying out the potentiostatic deposition at $0.65 \mathrm{~V}$ after transferring the $\mathrm{Pt} \mathrm{NFs} / \mathrm{CC}$ electrode into the $\mathrm{Cu}^{2+}$ containing electrolyte. Figure $2 \mathrm{~A}$ demonstrates that the morphology of Pt NFs is obviously unchanged after $\mathrm{Cu}$ modification, but the corresponding EDS map (Figure 2B) shows that $\mathrm{Pt}$ and $\mathrm{Cu}$ atoms are both uniformly dispersive in the $\mathrm{Pt} / \mathrm{Cu}$ deposited layers. The composition and chemical states of $\mathrm{Pt}$ and $\mathrm{Cu}$ elements in $\mathrm{Cu} / \mathrm{Pt} \mathrm{NFs} / \mathrm{CC}$ were further examined by X-ray photoelectron spectroscopy (XPS). Compared with the Pt NFs/CC, Cu element can be clearly observed in the wide survey spectrum of $\mathrm{Cu} / \mathrm{Pt} \mathrm{NFs} / \mathrm{CC}$, which is shown in Figure $\mathrm{S} 1$. The $\mathrm{Pt} 4 \mathrm{f}$ spectra (Figure 2C) display that $\mathrm{Pt} 4 \mathrm{f}$ region in the $\mathrm{Cu} / \mathrm{Pt} \mathrm{NFs} / \mathrm{CC}$ and $\mathrm{Pt} \mathrm{NFs} / \mathrm{CC}$ can be divided into two pairs of doublets. For Pt NFs/CC, two Pt $4 \mathrm{f}$ peaks were located at 71.3 and $74.7 \mathrm{eV}$, which can be assigned to 
the $\mathrm{Pt} 4 \mathrm{f} 7 / 2$ and $\mathrm{Pt} 4 \mathrm{f} 5 / 2$ of metallic $\mathrm{Pt}(0)$, respectively. The weaker doublet at 72.1 and $75.6 \mathrm{eV}$ can be assigned to less $\mathrm{Pt}(\mathrm{II})$ in the surface of the sample. Compared with $\mathrm{Pt} \mathrm{NFs} / \mathrm{CC}$, the $\mathrm{Pt} 4 \mathrm{f} 7 / 2$ and $\mathrm{Pt} 4 \mathrm{f}$ $5 / 2$ peaks of $\mathrm{Cu} / \mathrm{Pt} \mathrm{NFs} / \mathrm{CC}$ both shift to lower binding energies (71.1 and $74.5 \mathrm{eV}$ ), which confirms the electron interactions involving $\mathrm{Pt}$ and $\mathrm{Cu}$ in $\mathrm{Cu} / \mathrm{Pt} \mathrm{NFs} / \mathrm{CC}$. The $\mathrm{Cu} 2 \mathrm{p}$ spectrum (Figure 2D) shows that most of $\mathrm{Cu}$ is in the form of metallic $\mathrm{Cu}(0)$ (932.1 and $952 \mathrm{eV}$ ), but a signal from $\mathrm{Cu}(\mathrm{II})$ (934.4 and $954.7 \mathrm{eV}$ ) also exists. Based on the XPS results, $\mathrm{Pt}$ and $\mathrm{Cu}$ are mainly in zero valence on the surface of $\mathrm{Cu} / \mathrm{Pt} \mathrm{NFs} / \mathrm{CC}$, which is beneficial for the improvement of catalytic activity. However, the presence of $\mathrm{Cu}(\mathrm{II})$ which ascribed to the oxidation of surface $\mathrm{Cu}$ atoms in the air must be avoided by holding potential and fast transferring of the electrode in the experiment.

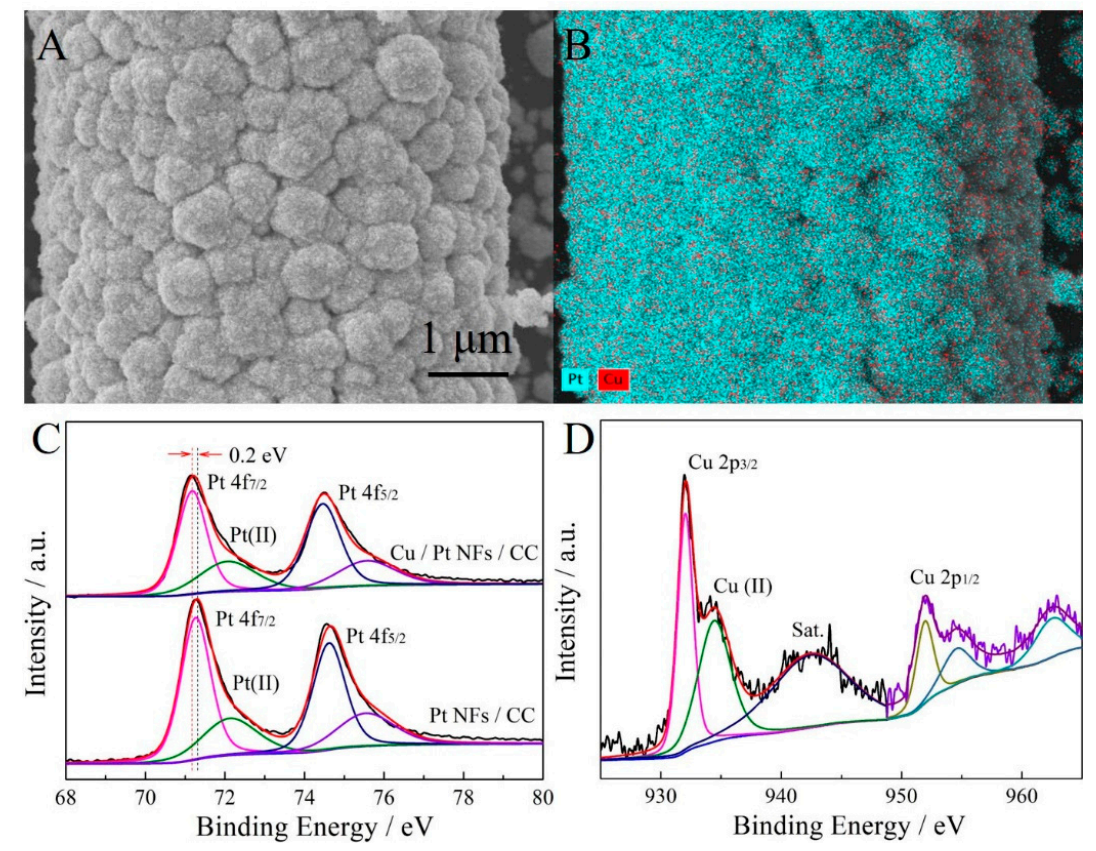

Figure 2. SEM image (A) and the corresponding elemental mapping image (B) of $\mathrm{Cu} / \mathrm{Pt} \mathrm{NFs} / \mathrm{CC}$, the blue and red colors in (B) correspond to Pt and Cu elements, respectively; Pt 4f XPS spectra (C) of $\mathrm{Pt} \mathrm{NFs} / \mathrm{CC}$ and $\mathrm{Cu} / \mathrm{Pt} \mathrm{NFs} / \mathrm{CC}, \mathrm{Cu} 2 \mathrm{p}$ XPS spectra (D) of $\mathrm{Cu} / \mathrm{Pt}$ NFs/CC.

\subsection{Assessment of $\mathrm{Cu}$ Sites and Coverage on $\mathrm{Cu} / \mathrm{Pt}$ NFs/CC}

$\mathrm{CV}$ for $\mathrm{Pt} \mathrm{NFs} / \mathrm{CC}$ in $0.5 \mathrm{M} \mathrm{H}_{2} \mathrm{SO}_{4}$ shows the typical hydrogen adsorption and desorption features for preferentially (100) oriented Pt surfaces. From the dash line in Figure 3A, peak 1 at ca. $0.14 \mathrm{~V}$ related to (110) step sites, peak 2 at ca. $0.28 \mathrm{~V}$ ascribed to (100) step sites, peak 3 at ca. $0.35 \mathrm{~V}$ attributed to (100) terraces and peak 4 at ca. $0.5 \mathrm{~V}$ related to the adsorption of (bi-) sulfates on (111) terraces [26,27]. In presence of $2 \mathrm{mM} \mathrm{Cu}^{2+}$ (solid curve in Figure 3A), three peaks are visible in the positive-going sweep besides peak 1 and 2: An impressive shoulder centered around $0.5 \mathrm{~V}$ is likely attributed to the $\mathrm{Cu}$ atoms adsorbed on $\mathrm{Pt}(110)$ sites [28], the sharper peak at $0.67 \mathrm{~V}$ is corresponding to the $\mathrm{Cu}$ atoms on $\mathrm{Pt}(100)$ step sites [29], and the peak at $0.75 \mathrm{~V}$ is ascribed to the $\mathrm{Cu}$ stripping from $\mathrm{Pt}(100)$ terraces [30]. In the negative-going sweep, there are two wide shoulders associated with the UPD (under potential deposition) of $\mathrm{Cu}$ at the potential region of $0.8-0.4 \mathrm{~V}$. Interestingly, no obvious signals for the bulk deposition of $\mathrm{Cu}$ between $0.4 \mathrm{~V}$ and $0.2 \mathrm{~V}$, which may be affected with the diffusion of $\mathrm{Cu}^{2+}$ in such a flower-like structure of Pt.

$\mathrm{Cu}$ stripping curve of $\mathrm{Cu} / \mathrm{Pt} \mathrm{NFs} / \mathrm{CC}$ in $0.5 \mathrm{M} \mathrm{H}_{2} \mathrm{SO}_{4}$ was measured to assess the active surface sites and coverage of $\mathrm{Cu}$ on Pt NFs. From the red curve in Figure 3B, the depressed hydrogen desorption peaks (peak 1, 2, and 3) and two stripping peaks (at $0.67 \mathrm{~V}$ and $0.75 \mathrm{~V}$ ) related to $\mathrm{Cu}$ atoms desorption from $\mathrm{Pt}(100)$ steps and terraces exist in the positive-going sweep of CV. Interestingly, no trace for $\mathrm{Cu}$ desorption from $\mathrm{Pt}(111)$ and the consistent current density of peak 4 can be ascribed to the priority 
nucleation and growth of $\mathrm{Cu}$ on the surface of $\mathrm{Pt}(100)$ [31]. Meanwhile, $\mathrm{Cu}$ preferential adsorption on the (100) terraces, the current density of $\mathrm{Cu}$ stripping from the (100) terrace is higher than that from the steps, conducing to the higher activity for nitrate transition to nitrite [24]. The slight diminution of the hydrogen desorption states and the overlapping (bi-) sulfate adsorption compared with $\mathrm{Pt}$ $\mathrm{NFs} / \mathrm{CC}$ (black curve in Figure 3B) correspond to the low $\mathrm{Cu}$ coverage on the surface of $\mathrm{Cu} / \mathrm{Pt} \mathrm{NFs} / \mathrm{CC}$. $\mathrm{Cu}$ coverage was calculated from the $\mathrm{H}$ desorption charge and $\mathrm{Cu}$ stripping charge by integrating the shaded areas depicted in Figure 3B [24]. As a result, $\mathrm{Cu} / \mathrm{Pt} \mathrm{NFs} / \mathrm{CC}$ with the coverage of ca. $8.7 \%$ not only provide the $\mathrm{Cu}$ active sites for the transition of nitrate to nitrite but also expose large $\mathrm{Pt}(100)$ surfaces for the nitrite selective reduction.
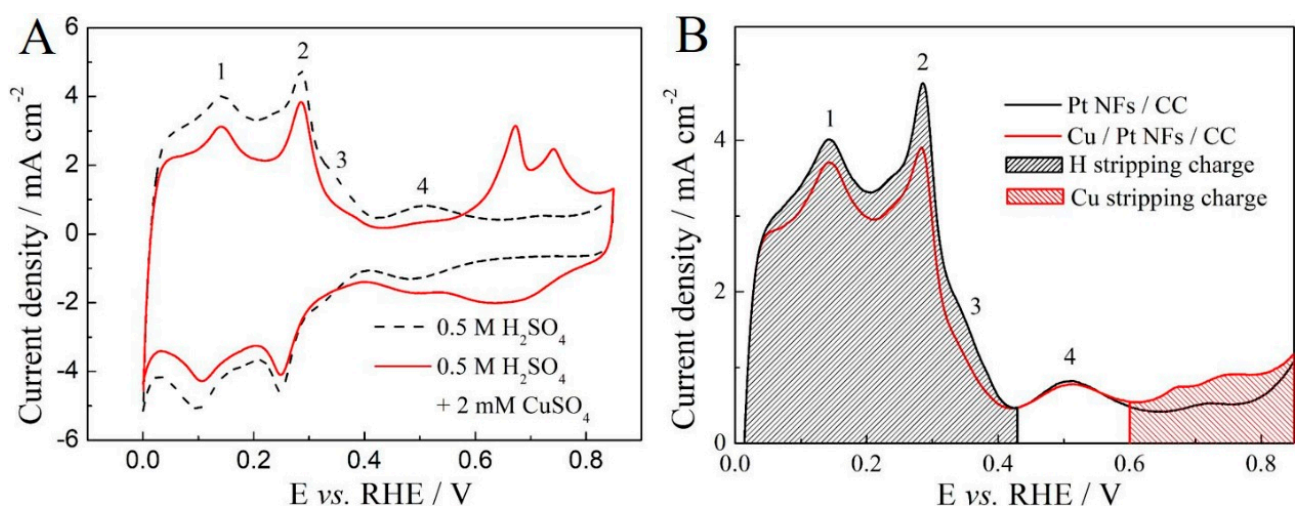

Figure 3. Cyclic Voltammetry of $\mathrm{Pt} \mathrm{NFs} / \mathrm{CC}(\mathbf{A})$ in a solution of absence (dash line) and presence of $2 \mathrm{mM} \mathrm{Cu}^{2+}$ (solid line); (B) $\mathrm{H}$ stripping curve of Pt NFs/CC (blank curve) and Cu stripping curve of $\mathrm{Cu} / \mathrm{Pt} \mathrm{NFs} / \mathrm{CC}$ (red curve) in $0.5 \mathrm{M} \mathrm{H}_{2} \mathrm{SO}_{4}$, scan rate is $20 \mathrm{mV} \mathrm{s}^{-1}$.

\subsection{Nitrate Reduction on $\mathrm{Cu} / \mathrm{Pt} \mathrm{NFs} / \mathrm{CC}$}

Figure $4 \mathrm{~A}$ compares the reduction of nitrite and nitrate on the $\mathrm{Pt} \mathrm{NFs} / \mathrm{CC}$ electrode in $0.1 \mathrm{M} \mathrm{NaOH}$. Clearly, a rather distinct shape of $\mathrm{CV}$ for nitrite reduction can be observed compared to the nitrate reduction. The reduction peaks at the potential below $0.2 \mathrm{~V}$ can be assigned to nitrite reduction at (110) step sites of Pt NFs [21]. Remarkably, three features could indicate the presence of well-ordered (100) facets in Pt NFs, which are the large reduction peaks corresponding to the nitrite conversion to ammonia at $0.2-0.5 \mathrm{~V}(\mathrm{R} 1)$, the broad peak for the ammonia oxidation to $\mathrm{N}_{2}$ at $0.55-0.8 \mathrm{~V}(\mathrm{O} 1)$, and the small reduction peak at ca. $0.56 \mathrm{~V}(\mathrm{R} 2)$ ascribed to the $\mathrm{N}_{2}$ evolution $[8,18]$. The presence of $\mathrm{N}_{2}$ evolution peak is strong evidence of the existence of broad (100) terraces in Pt NFs [21]. On the contrary, $\mathrm{Pt} \mathrm{NFs/CC} \mathrm{is} \mathrm{inactive} \mathrm{for} \mathrm{the} \mathrm{nitrate} \mathrm{reduction} \mathrm{in} \mathrm{alkaline} \mathrm{solution}[32,33]$ which can be deduced from the featureless voltammogram between 0 and $0.85 \mathrm{~V}$. However, as shown in Figure 4B, significant catalytic activities towards nitrate are displayed on $\mathrm{Cu} / \mathrm{Pt} \mathrm{NFs} / \mathrm{CC}$. In the first negative-going sweep from $0.2 \mathrm{~V}$, a reduction peak at ca. $0.1 \mathrm{~V}$ corresponding to nitrate reduction to nitrite on $\mathrm{Cu}$ sites deposited on $\mathrm{Pt} \mathrm{NFs}$, $\mathrm{Cu}$ adsorbed on $\mathrm{Pt}(100)$ sites is more active for nitrate reduction because of the easier adsorption of nitrate and subsequent electron transfer to form nitrite $[34,35]$. In the next cycle, the observation of peaks of R1, O1 and R2 indicates that the following nitrite reduction is catalyzed on the $\mathrm{Pt}(100)$ surfaces. Meanwhile, the decrements of current densities of peaks of R1, O1 and R2 are caused by the nitrate reduction peak with the increase of cycle numbers, proving that all the observed catalytic features are deduced from the nitrate reduction on the $\mathrm{Cu} / \mathrm{Pt} \mathrm{NFs} / \mathrm{CC}$. Surprisingly, nitrate selective reduction to $\mathrm{N}_{2}$ is exhibited on $\mathrm{Cu} / \mathrm{Pt} \mathrm{NFs} / \mathrm{CC}$ with the presence of peak $\mathrm{R} 2$, which means that large $\mathrm{Pt}(100)$ terraces are exposed on the $\mathrm{Cu} / \mathrm{Pt} \mathrm{NFs} / \mathrm{CC}$ with low $\mathrm{Cu}$ coverage. On the contrary, nitrate reduction mainly occurs on the $\mathrm{Cu}$ surfaces with increase of $\mathrm{Cu}$ coverage on Pt NFs, leading to lower activity for nitrate reduction and no $\mathrm{N}_{2}$ selective behavior. See results in Figure S2. 

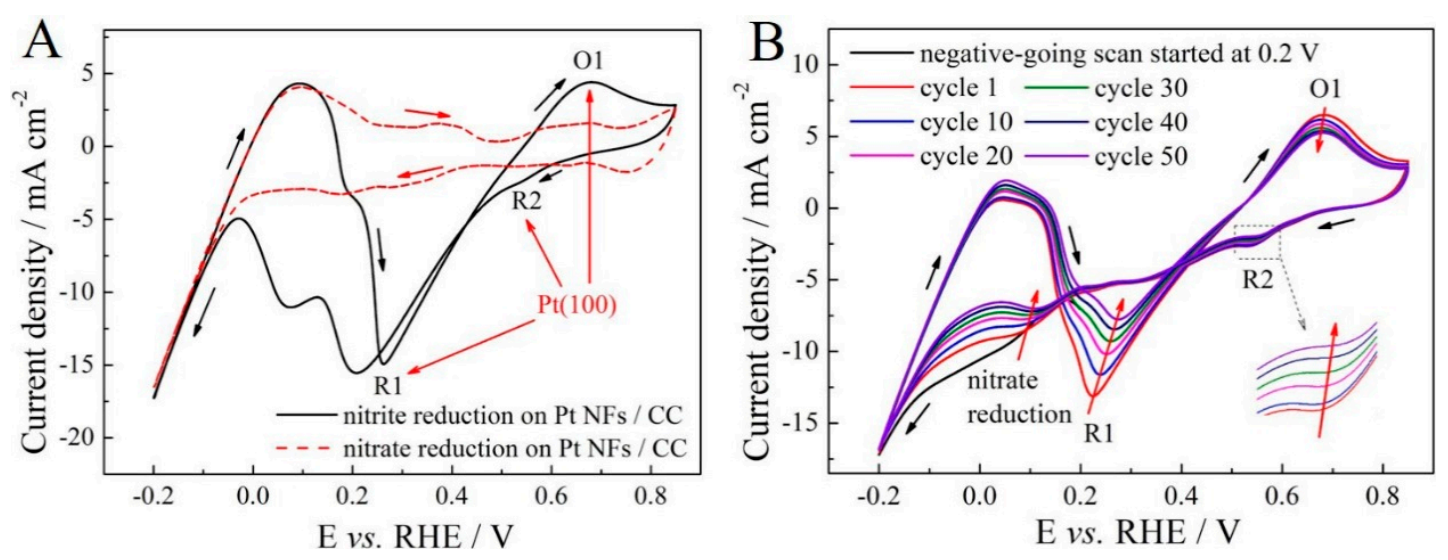

Figure 4. $\mathrm{CVs}$ of Pt NFs/CC (A) in $0.1 \mathrm{M} \mathrm{NaOH}$ containing $20 \mathrm{mM} \mathrm{NO}_{2}{ }^{-}$(solid line) and $20 \mathrm{mM} \mathrm{NO}_{3}{ }^{-}$ (dash line); $\mathrm{CVs}$ of $\mathrm{Cu} / \mathrm{Pt} \mathrm{NFs} / \mathrm{CC}(\mathbf{B})$ in $0.1 \mathrm{M} \mathrm{NaOH}$ containing $20 \mathrm{mM} \mathrm{NO}_{3}{ }^{-}$. Scan rate is $20 \mathrm{mV} \mathrm{s}^{-1}$.

The activity and selectivity of nitrate reduction on $\mathrm{Cu} / \mathrm{Pt} \mathrm{NFs} / \mathrm{CC}$ were further assessed by determination of the concentration of various products after $90 \mathrm{~min}$ of electrocatalysis. As shown in Figure $5 \mathrm{~A}$, a concentration of $\mathrm{NO}_{3}{ }^{-}-\mathrm{N}$ removal $\left(63 \mathrm{mg} \mathrm{L}^{-1}\right)$ confirms that $\mathrm{Cu}$ atoms covered on $\mathrm{Pt}$ $\mathrm{NFs}$ are active for nitrate to nitrite conversion. The detected concentration of $\mathrm{NO}_{2}{ }^{-}-\mathrm{N}$ and $\mathrm{NH}_{3}-\mathrm{N}$ is $0.02 \mathrm{mg} \mathrm{L}^{-1}$ and $16 \mathrm{mg} \mathrm{L}^{-1}$, which indicates the total reduction of nitrite and oxidation of ammonia to nitrogen containing gaseous compounds (gaseous compounds-N is $43 \mathrm{mg} \mathrm{L}^{-1}$ ). Though other gaseous products such as $\mathrm{NO}_{2}, \mathrm{NO}$, and $\mathrm{N}_{2} \mathrm{O}$ may also generate during the reaction [36,37], the main gaseous product deduced from the $\mathrm{CV}$ measurements is $\mathrm{N}_{2}$. Herein, the generated gaseous compounds after nitrate reduction on $\mathrm{Cu} / \mathrm{Pt} \mathrm{NFs} / \mathrm{CC}$ were detected by Gas chromatograph (GC), which is shown in Figure 5B. It is noticeable from the chromatogram that the $\mathrm{N}_{2}$ peak is well-separated from the minor peak for $\mathrm{H}_{2}$ (evolution in the negative potential region) in the gaseous compounds at the given GC conditions, indicating that $\mathrm{N}_{2}$ might be the major gaseous product for nitrate reduction. Combined with the electrochemical behaviors in CV curves, both of the ammonia oxidation and nitrite selective reduction to $\mathrm{N}_{2}$ on the exposed $\mathrm{Pt}(100)$ terraces in such nanostructured Pt NFs covered with a small amount of $\mathrm{Cu}$ contribute to the generation of $\mathrm{N}_{2}$. The major electrochemical reactions involved in the nitrate electroreduction are proposed in the Scheme $1[35,36,38]$. Detailed pathways of nitrate reduction on $\mathrm{Cu} / \mathrm{Pt} \mathrm{NFs} / \mathrm{CC}$ will be further studied in the future.
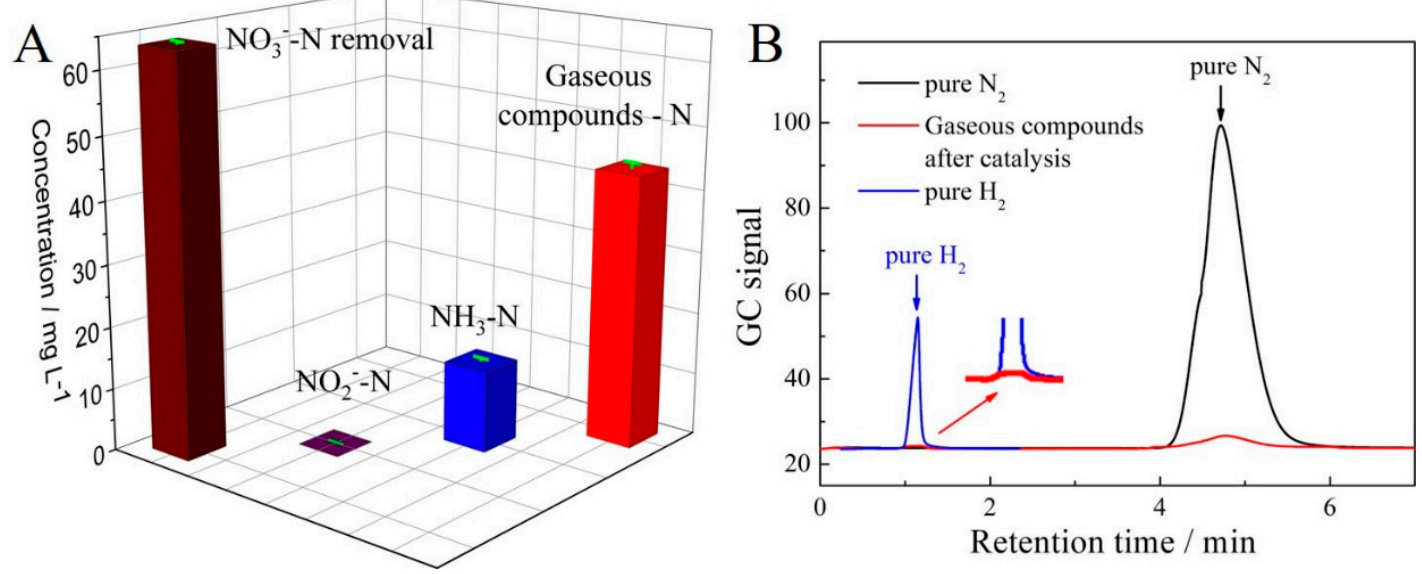

Figure 5. (A) Concentration of $\mathrm{NO}_{3}{ }^{-}-\mathrm{N}$ removal, $\mathrm{NO}_{2}{ }^{-}-\mathrm{N}, \mathrm{NH}_{3}-\mathrm{N}$ and gaseous compounds-N after electrocatalysis by $\mathrm{Cu} / \mathrm{Pt} \mathrm{NFs} / \mathrm{CC}$ in $0.1 \mathrm{M} \mathrm{NaOH}$ containing $20 \mathrm{mM} \mathrm{NO}_{3}^{-}\left(280 \mathrm{mg} \mathrm{L}^{-1}\right)$; (B) Chromatogram of the gaseous compounds after electrocatalysis by $\mathrm{Cu} / \mathrm{Pt} \mathrm{NFs} / \mathrm{CC}$. 


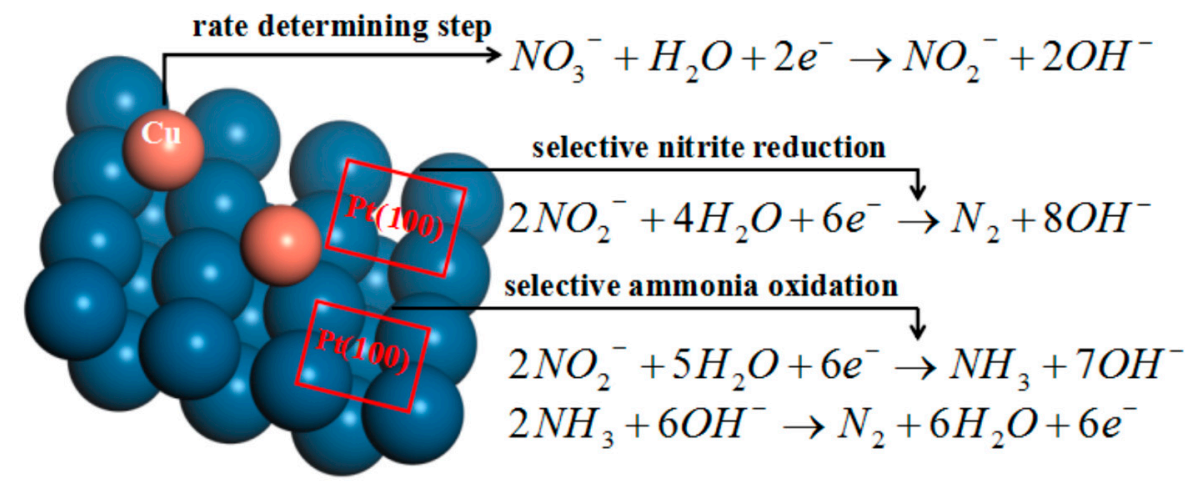

Scheme 1. Proposed electroreactions involved in the nitrate reduction on the $\mathrm{Cu} / \mathrm{Pt} \mathrm{NFs} / \mathrm{CC}(8.7 \%$ Cu coverage).

\section{Materials and Methods}

\subsection{Materials}

Sulfuric acid, $\mathrm{H}_{2} \mathrm{PtCl}_{6} \cdot 6 \mathrm{H}_{2} \mathrm{O}, \mathrm{CuSO}_{4} \cdot 5 \mathrm{H}_{2} \mathrm{O}, \mathrm{NaNO}_{3}, \mathrm{NaNO}_{2}$ were purchased from Sinopharm Chemical Reagent Co., Ltd., and $\mathrm{NaOH}$ was purchased from Alfa Aesar (Shanghai, China). Carbon cloths were obtained from Ce Tech Co., Ltd (Taichung, Taiwan). All aqueous solutions were freshly prepared with ultrapure water $(\geq 18 \mathrm{M} \Omega \mathrm{cm})$. All glassware was immersed in the concentrated sulfuric acid solution to stay overnight and rinsed with the ultrapure water for several times before use. Prior to the experiments, oxygen was removed by bubbling argon for at least $30 \mathrm{~min}$.

\subsection{Preparation of $\mathrm{Cu} / \mathrm{Pt} \mathrm{NFs} / \mathrm{CC}$}

Two-step electrodeposition processes were used to prepare $\mathrm{Cu} / \mathrm{Pt} \mathrm{NFs} / \mathrm{CC}$. To improve the surface hydrophilicity, carbon cloths were immersed in a $6 \mathrm{M} \mathrm{HNO}_{3}$ solution for 30 min sonication and rinsed with the ultrapure water before use. First, Pt NFs were grown onto the carbon cloth via potentiostatic deposition in the solution of $2 \mathrm{mM} \mathrm{H}_{2} \mathrm{PtCl}_{6}+0.5 \mathrm{M} \mathrm{H}_{2} \mathrm{SO}_{4}$ at $-0.1 \mathrm{~V}$ for $1800 \mathrm{~s}$. Then, the Pt NFs/CC electrode was treated as the supporting material for carrying out the potentiostatic deposition of $\mathrm{Cu}$ atoms in the solution of $2 \mathrm{mM} \mathrm{CuSO}_{4}+0.5 \mathrm{M} \mathrm{H}_{2} \mathrm{SO}_{4}$ at potential of $0.65 \mathrm{~V}$ for $300 \mathrm{~s}$. The obtained electrode was denoted as $\mathrm{Cu} / \mathrm{Pt} \mathrm{NFs} / \mathrm{CC}$ electrode.

\subsection{Characterizations and Electrochemical Measurements}

The morphology and structure of electrodes were studied by scanning electron microscope (SEM, Zeiss, Gemini300, Oberkochen, Germany). The elemental analyses were conducted with an energy dispersive X-ray spectrometer (EDS) equipped on the Zeiss. TEM and HRTEM images of the Pt NFs were obtained using a JEM-2100 high-resolution transmission electron microscope (Tokyo, Japan). X-ray photoelectron spectroscopy (XPS) was operated on a Thermo ESCALAB 250 system (Waltham, MA, USA). All electrochemical experiments were performed by using a CHI 760C electrochemical workstation in a conventional three-electrode cell, which equipped with an reversible hydrogen electrode (RHE) reference electrode and a platinum sheet as a counter electrode. All potentials mentioned below are referred to the RHE. To avoid $\mathrm{Cu}$ oxidation, faster transfer of the $\mathrm{Cu} / \mathrm{Pt} \mathrm{NFs} / \mathrm{CC}$ electrode is needed for next electrochemical measurement.

\subsection{Product Analysis}

The concentration of $\mathrm{NO}_{3}{ }^{-}-\mathrm{N}$ was measured by an ion chromatography system (Dionex ICS-1500, Sunnyvale, CA, USA) equipped with a Dionex IonPac AS11-HC anion exchange column. The standard colorimetric method was employed to determine the concentration of $\mathrm{NO}_{2}{ }^{-}-\mathrm{N}, \mathrm{NH}_{3}-\mathrm{N}$ and total nitrogen (TN) in solution by the use of a UV-visible spectrophotometer (Thermo Evolution 220, 
Waltham, MA, USA). The concentration of $\mathrm{NO}_{3}{ }^{-}-\mathrm{N}$ removal and gaseous compounds- $\mathrm{N}$ was calculated by the initial concentration $\left(20 \mathrm{mM} \mathrm{L}^{-1}, 280 \mathrm{mg} \mathrm{L}^{-1}\right)$ subtracting the detected concentration of $\mathrm{NO}_{3}{ }^{-}-\mathrm{N}$ and TN, respectively. Gas chromatograph (GC, GC7290, Shanghai, China) was used at the end of the electrocatalysis experiment (ca. $90 \mathrm{~min}$ ) for the qualitative determination of $\mathrm{N}_{2}$ in the sealed cell.

\section{Conclusions}

Pt nanoflowers featuring a preferential (100) orientation were electrodeposited on carbon cloth, and then $\mathrm{Cu}$ atoms were deposited on the Pt NFs at the electrodeposition potential of $0.65 \mathrm{~V}$. The activity and selectivity of the nitrate reduction on $\mathrm{Cu}$ modified Pt NFs are pronounced depending on the $\mathrm{Cu}$ coverage and exposed $\mathrm{Pt}(100)$ terraces. With a lower $\mathrm{Cu}$ surface coverage (ca. $8.7 \%$ ) on $\mathrm{Cu} / \mathrm{Pt} \mathrm{NFs} / \mathrm{CC}$, $\mathrm{Cu}$ atoms adsorbed on the $\mathrm{Pt}(100)$ sites could enhance the activity of nitrate reduction, meanwhile, the presence of broad $\mathrm{Pt}(100)$ terraces could result in $\mathrm{N}_{2}$ generation associated with the selective processes of ammonia oxidation and nitrite reduction on $\mathrm{Pt}(100)$ terraces. On the contrary, with the increase of $\mathrm{Cu}$ atoms adsorbed on $\mathrm{Pt}(100)$ sites, the nitrate reduction activity decreases and the $\mathrm{N}_{2}$ selective step is hindered. The results suggest that $\mathrm{Cu}$ modified Pt nanoflowers with preferential (100) surfaces could be a promising electrocatalyst in the nitrate removal attributed to the large specific surface area, low cost and flexibility in application.

Supplementary Materials: The following are available online at http://www.mdpi.com/2073-4344/9/6/536/s1, Figure S1: XPS survey spectra of Pt NFs/CC and Cu/Pt NFs/CC, Figure S2: (A)H stripping curve of Pt NFs/CC (blank curve) and $\mathrm{Cu}$ stripping curve of $\mathrm{Cu}_{\text {depo } 0.2 \mathrm{~V}} / \mathrm{Pt} \mathrm{NFs} / \mathrm{CC}$ (red curve) in $0.5 \mathrm{M} \mathrm{H}_{2} \mathrm{SO}_{4}$, (B) CVs of Cudepo $0.2 \mathrm{~V} / \mathrm{Pt}$ $\mathrm{NFs} / \mathrm{CC}$ in $0.1 \mathrm{M} \mathrm{NaOH}$ containing $20 \mathrm{mM} \mathrm{NO}_{3}{ }^{-}$. Scan rate is $20 \mathrm{mV} \mathrm{s}^{-1}$.

Author Contributions: T.C., H.M. proposed the concept and supervised the research work. Y.L., L.L., Y.Z., S.S. and R.J. designed and performed the experiments. All authors analyzed the data and wrote the paper.

Funding: This research was funded by "National Natural Science Foundation of China, grant number 21603122", "Doctoral Research Fund of Shandong Jianzhu University, grant number XNBS1538", "Key Research and Development Project of Shandong Province, grant number S18015Z" and "Project of Shandong Province Higher Educational Science and Technology Program, grant number J16LA04".

Conflicts of Interest: The authors declare no conflict of interest.

\section{References}

1. Duca, M.; Koper, M.T.M. Powering denitrification: The perspectives of electrocatalytic nitrate reduction. Energy Environ. Sci. 2012, 5, 9726-9742. [CrossRef]

2. Kuang, P.; Natsui, K.; Einaga, Y. Comparison of performance between boron-doped diamond and copper electrodes for selective nitrogen gas formation by the electrochemical reduction of nitrate. Chemosphere 2018, 210, 524-530. [CrossRef] [PubMed]

3. Ghafari, S.; Hasan, M.; Aroua, M.K. Bio-electrochemical removal of nitrate from water and wastewater-A review. Bioresour. Technol. 2008, 99, 3965-3974. [CrossRef] [PubMed]

4. Garcia-Segura, S.; Lanzarini-Lopes, M.; Hristovski, K.; Westerhoff, P. Electrocatalytic reduction of nitrate: Fundamentals to full-scale water treatment applications. Appl. Catal. B Environ. 2018, 236, 546-568. [CrossRef]

5. Katsounaros, I.; Kyriacou, G. Influence of nitrate concentration on its electrochemical reduction on tin cathode: Identification of reaction intermediates. Electrochim. Acta 2008, 53, 5477-5484. [CrossRef]

6. de Vooys, A.C.A.; van Santen, R.A.; van Veen, J.A.R. Electrocatalytic reduction of $\mathrm{NO}_{3}{ }^{-}$on palladium/copper electrodes. J. Mol. Catal. A Chem. 2000, 154, 203-215. [CrossRef]

7. Duca, M.; Cucarella, M.O.; Rodriguez, P.; Koper, M.T.M. Direct reduction of nitrite to $\mathrm{N}_{2}$ on a Pt(100) electrode in alkaline media. J. Am. Chem. Soc. 2010, 132, 18042-18044. [CrossRef]

8. Duca, M.; Figueiredo, M.C.; Climent, V.; Rodriguez, P.; Feliu, J.M.; Koper, M.T.M. Selective catalytic reduction at quasi-perfect $\operatorname{Pt}(100)$ domains: A universal low-temperature pathway from nitrite to $\mathrm{N}_{2}$. J. Am. Chem. Soc. 2011, 133, 10928-10939. [CrossRef] [PubMed]

9. de Groot, M.T.; Koper, M.T.M. The influence of nitrate concentration and acidity on the electrocatalytic reduction of nitrate on platinum. J. Electroanal. Chem. 2004, 562, 81-94. [CrossRef] 
10. Rosca, V.; Duca, M.; de Groot, M.T.; Koper, M.T.M. Nitrogen cycle electrocatalysis. Chem. Rev. 2009, 109, 2209-2244. [CrossRef]

11. Duca, M.; Sacre, N.; Wang, A.; Garbarino, S.; Guay, D. Enhanced electrocatalytic nitrate reduction by preferentially-oriented (100) PtRh and PtIr alloys: The hidden treasures of the 'miscibility gap'. Appl. Catal. B Environ. 2018, 221, 86-96. [CrossRef]

12. Duca, M.; Kightley, J.; Garbarino, S.; Guay, D. The art of decoration: Rhodium-modified platinum films with preferential (100) orientation as electrocatalysts for nitrate reduction and dimethyl ether oxidation. J. Phys. Chem. C 2017, 121, 15233-15247. [CrossRef]

13. Ehrenburg, M.R.; Danilov, A.I.; Botryakova, I.G.; Molodkina, E.B.; Rudnev, A.V. Electroreduction of nitrate anions on cubic and polyoriented platinum nanoparticles modified by copper adatoms. J. Electroanal. Chem. 2017, 802, 109-117. [CrossRef]

14. Katsounaros, I.; Figueiredo, M.C.; Chen, X.T.; Calle-Vallejo, F.; Koper, M.T.M. Interconversions of nitrogen-containing species on $\mathrm{Pt}(100)$ and $\mathrm{Pt}(111)$ electrodes in acidic solutions containing nitrate. Electrochim. Acta 2018, 271, 77-83. [CrossRef]

15. Molodkina, E.B.; Danilov, A.I.; Ehrenburg, M.R.; Feliu, J.M. Regularities of nitrate electroreduction on $\mathrm{Pt}(\mathrm{S})[\mathrm{n}(100) \times(110)]$ stepped platinum single crystals modified by copper adatoms. Electrochim. Acta 2018, 278, 165-175. [CrossRef]

16. Kato, M.; Okui, M.; Taguchi, S.; Yagi, I. Electrocatalytic nitrate reduction on well-defined surfaces of tin-modified platinum, palladium and platinum-palladium single crystalline electrodes in acidic and neutral media. J. Electroanal. Chem. 2017, 800, 46-53. [CrossRef]

17. Souza-Garcia, J.; Ticianelli, E.A.; Climent, V.; Feliu, J.M. Nitrate reduction on Pt single crystals with Pd multilayer. Electrochim. Acta 2009, 54, 2094-2101. [CrossRef]

18. Chen, T.; Li, H.J.; Ma, H.Y.; Koper, M.T.M. Surface modification of Pt(100) for electrocatalytic nitrate reduction to dinitrogen in alkaline solution. Langmuir 2015, 31, 3277-3281. [CrossRef]

19. Duca, M.; van der Klugt, B.; Hasnat, M.A.; Machida, M.; Koper, M.T.M. Electrocatalytic reduction of nitrite on a polycrystalline rhodium electrode. J. Catal. 2010, 275, 61-69. [CrossRef]

20. Reyter, D.; Belanger, D.; Roue, L. Study of the electroreduction of nitrate on copper in alkaline solution. Electrochim. Acta 2008, 53, 5977-5984. [CrossRef]

21. Duca, M.; Rodriguez, P.; Yanson, A.I.; Koper, M.T.M. Selective electrocatalysis on platinum nanoparticles with preferential (100) orientation prepared by cathodic corrosion. Top. Catal. 2014, 57, 255-264. [CrossRef]

22. Wang, Q.F.; Zhao, X.B.; Zhang, J.F.; Zhang, X.W. Investigation of nitrate reduction on polycrystalline Pt nanoparticles with controlled crystal plane. J. Electroanal. Chem. 2015, 755, 210-214. [CrossRef]

23. Zhang, Y.; Shao, Z.W.; Shen, Q.; Li, M.Y.; Xu, L.; Luo, Z.M. Aqueous preparation of platinum nanoflowers on three-dimensional graphene for efficient methanol oxidation. Catalysts 2018, 8, 519. [CrossRef]

24. Roy, C.; Deschamps, J.; Martin, M.H.; Bertin, E.; Reyter, D.; Garbarno, S.; Roue, L.; Guay, D. Identification of $\mathrm{Cu}$ surface active sites for a complete nitrate-to-nitrite conversion with nanostructured catalysts. Appl. Catal. B Environ. 2016, 187, 399-407. [CrossRef]

25. Ponrouch, A.; Garbarino, S.; Bertin, E.; Andrei, C.; Botton, G.A.; Guay, D. Highly porous and preferentially oriented $\{100\}$ platinum nanowires and thin films. Adv. Funct. Mater. 2012, 22, 4172-4181. [CrossRef]

26. Solla-Gullón, J.; Rodríguez, P.; Herrero, E.; Aldaz, A.; Feliu, J.M. Surface characterization of platinum electrodes. Phys. Chem. Chem. Phys. 2008, 10, 1359-1373. [CrossRef] [PubMed]

27. Roy, C.; Bertin, E.; Martin, M.H.; Garbarino, S.; Guay, D. Hydrazine oxidation at porous and preferentially oriented $\{100\} \mathrm{Pt}$ thin films. Electrocatalysis 2013, 4, 76-84. [CrossRef]

28. Buller, L.J.; Herrero, E.; Gómez, R.; Feliu, J.M.; Abruna, H.D. Induced adsorption of sulfate/bisulfate anions by submonolayer amounts of copper on deliberately stepped Pt surfaces. J. Chem. Soc. Faraday Trans. 1996, 92, 3757-3762. [CrossRef]

29. Nishihara, C.; Nozoye, H. Underpotential deposition of copper on $\mathrm{Pt}(\mathrm{S})-[n(111) \times(100)]$ electrodes in sulfuric acid solution. J. Electroanal. Chem. 1995, 386, 75-82. [CrossRef]

30. Francke, R.; Climent, V.; Baltruschat, H.; Feliu, J.M. Electrochemical deposition of copper on stepped platinum surfaces in the $\left[\begin{array}{lll}0 & 1 & 1^{-}\end{array}\right]$zone vicinal to the $\left(\begin{array}{lll}1 & 0 & 0\end{array}\right)$ plane. J. Electroanal. Chem. 2008, 624, 228-240. [CrossRef]

31. Rudnev, A.V.; Molodkina, E.B.; Ehrenburg, M.R.; Fedorov, R.G.; Danilov, A.I.; Polukarov, Y.M.; Feliu, J.M. Methodical aspects of studying the electroreduction of nitrate on modified single crystal $\mathrm{Pt}(\mathrm{hkl})+\mathrm{Cu}$ electrodes. Russ. J. Electrochem. 2009, 45, 1052-1063. [CrossRef] 
32. Dima, G.E.; de Vooys, A.C.A.; Koper, M.T.M. Electrocatalytic reduction of nitrate at low concentration on coinage and transition-metal electrodes in acid solutions. J. Electroanal. Chem. 2003, 554, 15-23. [CrossRef]

33. Yang, J.; Sebastian, P.; Duca, M.; Hoogenboom, T.; Koper, M.T.M. pH dependence of the electroreduction of nitrate on Rh and Pt polycrystalline electrodes. Chem. Commun. 2014, 50, 2148-2151. [CrossRef] [PubMed]

34. Reyter, D.; Odziemkowski, M.; Bélanger, D.; Roué, L. Electrochemically activated copper electrodes: Surface characterization, electrochemical behavior, and properties for the electroreduction of nitrate. J. Electrochem. Soc. 2007, 154, K36-K44. [CrossRef]

35. Pérez-Gallent, E.; Figueiredo, M.C.; Katsounaros, I.; Koper, M.T.M. Electrocatalytic reduction of nitrate on copper single crystals in acidic and alkaline solutions. Electrochim. Acta 2017, 227, 77-84. [CrossRef]

36. Reyter, D.; Chamoulaud, G.; Bélanger, D.; Roué, L. Electrocatalytic reduction of nitrate on copper electrodes prepared by high-energy ball milling. J. Electroanal. Chem. 2006, 596, 13-24. [CrossRef]

37. Öznülüer, T.; Özdurak, B.; Öztürk Doğan, H. Electrochemical reduction of nitrate on graphene modified copper electrodes in alkaline media. J. Electroanal. Chem. 2013, 699, 1-5. [CrossRef]

38. Katsounaros, I.; Figueiredo, M.; Calle-Vallejo, F.; Li, H.J.; Gewirth, A.; Markovic, N.; Koper, M.T.M. On the mechanism of the electrochemical conversion of ammonia to dinitrogen on $\operatorname{Pt}\left(\begin{array}{ll}0 & 0\end{array}\right)$ in alkaline environment. J. Catal. 2018, 359, 82-91. [CrossRef]

(C) 2019 by the authors. Licensee MDPI, Basel, Switzerland. This article is an open access article distributed under the terms and conditions of the Creative Commons Attribution (CC BY) license (http://creativecommons.org/licenses/by/4.0/). 